\title{
Literary and Poetic Aspects of Ogun Deity: A Study of Ogun Festival in Ondoland
}

\author{
Dr. Olu-Osayomi Olusegun \\ Department of Languages \& Literary Studies, School of Education and Humanities, \\ Babcock University, Ilishan-Remo, Ogun State
}

\begin{abstract}
Ogun festival among the Yoruba of Western Nigeria and among Africans generally, have been the subject of many learned discourses. This is largely illustrative of the popularity of the deity as an integral aspect of cultural heritage and as a vehicle for social cohesion. However, the poetic aspect of how Ogun deity is worshipped during Ogun festival by the Yoruba particularly the Ondo people, demands a deeper religious appreciation on which researchers of comparative mythology and religion have not done enough. This thus constitutes the subject of this paper. The paper, therefore, focuses on the exploration of the literary and poetic aspects of Ogun deity in relation to Ogun festival in Ondoland. It further examines the origin and role of Ogun deity in Yorubaland, Ogun in Ondo, the cultural basis of Ogun in Ondo, cardinal attributes of Ogun deity, role of worshippers in Ogun festival, mode of worship and its importance, Ogun and social harmony in Ondo; in order to appraise the immense significance of the various exploits and life - style that were recorded about Ogun deity in Ondoland. The aesthetic value or merit of this poetic form, however, is to the Ondo secondary to its religious significance. This is discussed from a mythological and spiritual perspectives. The paper establishes that the worship of Ogun deity is an oral tradition deeply rooted in the culture of the people and that it is essential to preserve its indigenous nature. It reveals that Ogun deity plays pivotal roles in the social, religious and political milieu of the Ondo people. The paper demonstrates that the worship of Ogun deity in Ondoland is not only a way of life but it has also transcended traditional, christian and muslim beliefs. It concludes that in Ondo, Ogun deity worship with its rich literary and poetic features is a source of unity in the society, and in a position to derive economic gains relating to tourist activities. However, it is imperative that African countries implement credible cultural policies to index, protect and promote the still existing deitist festivals and a somewhat delicate cultural heritage.
\end{abstract}

Methodology: The present paper has benefited from earlier writing on Yoruba Oral Poetry in that they have pointed the way to further analysis which is attempted here. The paper is based on the field - work which I carried out on the literary and poetic aspects of Ogun Deity, the recorded samples are used in this paper. All the recorded samples came mostly from the blacksmiths of Ogbonkowo area in Ondo, Ondo State. All unacknowledged quotations are from my personal collections. The recordings were done on magnetic and visual tapes, and the sounds transcribed as recorded.

To translate ofo Ogun (Ogun incantations) into English and yet preserve their exact meaning is not an easy task. I have, however, tried to meet the difficulty by being rather literal and keeping very close to the original in my translation.

\section{INTRODUCTION}

\section{Origin and Role of Ogun Deity in Yorubaland}

The Yoruba can be found along the western coast of Africa. Yorubaland (Yoruba: Ile - Yoruba), the cultural region of the Yoruba people, south - western Nigeria, comprises today's Oyo, Osun, Ogun, Kwara, Ondo, Ekiti, Lagos as well as part of Kogi bound together by language, traditions and religious beliefs and practices. Those who founded Ondo, at the beginning of the $16^{\text {th }}$ century, according to Rev. Samuel Johnson (1957) were no common place wayfarers with prosaic, pedestrian pedigree. They were men and women enveloped in royal garments straight from the place of the Alaafin of Oyo, the then powerful leader of the Yoruba race. Among the cities, towns and villages that make up Yoruba nation, Ondo is blessed with unique history; it is perhaps the only major Yoruba town whose founding King was a woman. "In the years of yore, the present Ondo was no great town; 
just a sparsely populated settlement with scattered huts where a primitive race engaged in farming and blacksmithing" (Explore Newspaper, 2010:31).

Ogun is one of the earliest Yoruba deities that are said to derive their power directly from 'Olodumare' or 'Olorun' (the Supreme Being, or God; the sustainer and upholder of the universe). Ogun is an important and highly regarded Yoruba deity. He is described as a 'a pan-Yoruba deity of fairly uniform character and significance', the 'deity of iron and war' (J.D.Y Peel, 1994:1).

According to Yoruba mythology, Ogun was a hunter who usually came down from heaven by a 'spider's thread upon the primordial mashy waste' (Idowu, 1962:85) for his hunting expedition. This was before the earth was founded. "There was a critical lacuna, in the finishing of the universe as a unified cohesive form, especially in terms of linkages between physical and metaphysical beings and between those beings and the forces of nature" (Yakubu, 2009: 43).

However, 'when the earth was founded and its furniture arranged' (Idowu, 1962: 85), Ogun and other deities decided to come down from heaven in order to take over the affairs of the world. But they were unable to get through the bush 'at a place of "no road", and came 'to a halt' (Idowu, 162:85) and resigned by submitting to fate. Orisanla 'tried to cut a way through, but his machete bent because it was lead. Of all the divinities, it was only Ogun who possessed the implement which was adequate for the task' (Idowu, 1902:86). So, 'he cleared a part with his magical tool. As a result of this, Ogun was invited to be their chief or head' (Jacob, 1977:25). By virtue of his power and status, Ogun received the title of Osin - Imale - Chief among the divinities' (Idowu, 1962:86) when they arrived at Ile - Ife, the "headquarters".

Therefore, Ogun was unable to adjust himself to live a settled - community life because of his prowess in hunting and carnage. So, he decided to dwell on "Top of the hill" - Ori - Oke, as "the lone One'.

After a short time, Ogun 'became tired of his seclusion and sought the settled life which he once rejected. At first, his fierce and forbidding appearance made it impossible for him to find a home in any community (Idowu, 1962:86). The elders of Ire would achieve what other gods fail to achieve. They begged and persuaded Ogun into accepting to become their king. Ogun is crowned the king of Ire "Ogun, On'ire - Ogun, the lord of Ire", and that becomes the beginning of a major travail of the people of the town. Thence, 'Ogun - the great warrior, exhibitionist stud, annihilator and imbiber extra ordinaire - was leading his men in battle, doing what he did best - slaughtering the enemies of his people' (Udu Yakubu, 2009: 43). His relationship with man is one of perpetual hazard. The traditional bard at Ire - Ekiti, according to Oyin Ogunba (2005:14) captured this ghoulish nature of Ogun in their chant when they sing:

Ojilelegbeje oniyan

Kee suse ninu oko Ogun

Ororo ebibu $n i$

Se li ei lorun,

Eyi koo ba loren

Seli ei lori

\section{One thousand four hundred and forty people}

Working in Ogun's farm

They are all in bits and pieces,

Those of them who have heads

Have no necks

Those who have necks Have no heads.

The people of Ire mourn the day they invited a god to be their king. As an annihilator, neither Ogun nor his sword understands the word "retreat" in war. His "superfluity of naughtiness" and "sadistic pleasure in wickedness" is made clear in the saying:

Nibo l'ati pade re?

A pade re n'ibi ija;

A pade re n'ibi ita;

A pde re n'ibi agbara eje

blood,

Gbe nda ni l'orun bi omi ago.

(Idowu, 1962: 80).

\section{Where does one meet him?}

One meets him in the place of battle;

One meets him in the place of wrangling;

One meets him in the place where torrents of

Fill with longing as a cup of water does the thirsty 
According to John Omolafe (1988:36), Ogun's devotees fondly address him as 'Ogun Alada meji; o nfi kan sako, o nfi kan yena' ('Ogun, the owner of two cutlasses; with one, he cultivates the farm, and with the other he clears the road'). Ogun is greatly honoured as the great master artist; and as the god of iron and steel; he is accorded great respect among the other deities. 'He is universally acknowledged; according to E.Bolaji Idowu (1962:85), in the indigenous belief of the Yoruba as a most indispensable divinity, in as much as all iron and steel belong to him.

Among the Yoruba pantheon (Orisanla; sometimes called Obatala, Orunmila, Esu, Sango, Saponna, Ela etc), Ogun occupies an important place and wields great power. He is held to be in control of everything that is made of iron. In order not to incur Ogun's wrath, his devotees handle with every care metal tools or things made of iron, such as knives, cutlasses and automobiles. As a matter of fact (O.B Abiodun, 2003:208), in the use of metal implements, devotees of Ogun are careful to follow the rules and regulations spelt out by Ogun. This explains why drivers, farmers and blacksmiths offer regular sacrifices to Ogun, so as to win his favor in whatever they do.

In the words of Olusegun Oladipo (1988:89), Ogun is believed to have put finishing touches to the creation of man; he made human bones and assembled them. He completed Orisanla's job of moulding the physical body of man by the cutting or craving of hands and legs to the shapes. In traditional Yoruba society, 'such things as circumcision, tribal marking, tattooing, or any surgical operations that may be necessary to keep man in good health' (E.Bolaji Idowu, 1962:87) are associated with Ogun.

So great and famous was his prowess all over Yorubaland then that it was commonly acknowledged that he never lost any battle to an opponent. Indeed, Ogun could have been described as a prodigy of war. The secrets of his successes laid not only in his gallantry at war but also in the skills with which he was able to manipulate his implements of war which were believed to have been charged with fire. These implements were derived from steel and they included guns, cutlasses and matchets. So, the basis of his military successes rested on the effectiveness of steel. These achievements were renowned all over Yorubaland, including places like Ile - Ife, Ire, Oyo, Ekiti and Ondo. So in these places, it was a common practice to chant incantations and songs in praise of Ogun.

\section{Origin of Ogun Deity in Ondo}

Ondo, the second Largest City in Ondo State (created on 3 February 1976 from the former Western State), Nigeria, is strategically sited at the intersection of roads from Ile - Ife, Akure, Okitipupa and other major towns in that axis. As a result of its location, Ondo was a major transit town from Lagos and Ibadan to other towns in the north - eastern axis of Yorubaland, especially during the many wars that ravaged the Yoruba nation in the $19^{\text {th }}$ century. It steadily emerged as a major conduit for goods from Lagos and to other parts of Yorubaland. From then, Ondo started asserting itself as an important community in the Yoruba nation.

Early in the history of Ondo, wars played a very prominent role in her relationship with her neighboring towns. Intermittent wars came successively and Ondo was not able to ward off her enemies easily. Also, it was about this time that the military fame of Ogun spread all over Yorubaland. So, Ondo then decided to seek Ogun's assistance. This was what led him to depart Ile Ife, his premodial home. This ceremonious departure was to create a "land - mark" in the history of the Ondo people. This is because with the subsequent warfares, Ogun was able to solve the problems of external invasion for a very long time, and even afterwards. Moreover, Ogun's prowess was so great and vivid in the minds of the people that until this day, Ondos have vowed never to be defeated again. This bears some elements of truth because the people always strove to fight with same zeal as their fore - fathers acquired from Ogun. This is a lasting impact because Ogun remains a source of psychological inspiration during war.

\section{Ogun Diety in Ondo}

In appreciation of Ogun' achievements, the Ondos then started to worship him and they were known as "children of Ogun". Ogun worship later on turned out to be a source of unity in the society. This will be discussed later in this paper.

One thing that must be appreciated is the relationship of Ogun with the Supreme God. All Ogun worshippers believe firmly in the existence of a Supreme Being (Eledumare) or God. Ogun, they believe, is one of the several deities chosen by Eledumare to represent Him here on earth. In other 


\section{Dr. Olu-Osayomi Olusegun}

words, Ogun is to act as a go - between for God and man by occupying that vacuum which is created by man's yearnings for direct contact with God.

The role of Ogun amongst the other gods is a very important one because steel or iron plays a very prominent part in the daily life of the individual. This is why apart from Sango the god of thunder, Ogun is the most significant deity in Yorubaland. For the Ondos, Ogun is even more important by virtue of his military achievements in Ondo history.

This is a vague analysis of the foundation and development of Ogun worship in Yorubaland and Ondo especially. It should be realized that Ogun worship is not restricted to only these areas because it includes those places where the power of Ogun as god of iron is acknowledged. This is why we discover that it takes place in certain parts of Iboland and Benin. However, that of the Ondo is unique, because it has developed into a cult in which most members of the community in Ondo participate.

\section{The Cultural Basis of Ogun Deity in Ondo}

In Ondo, the worship of Ogun culminates in an annual festival which is called the Ogun festival. This festival is of such importance that it happens to be the most significant local festival in town. It is a festival held not only in commemoration of the achievements and power of Ogun but it is also used as a means of appeasing Ogun for the short - comings of the people over the past year. Above all, this festival serves as the only opportunity of bringing all the worshippers together in the year. Through it, they are all unified physically and spiritually under the common acknowledgment of Ogun's power. This is why everyone looks forward every year to the festival.

The worship of Ogun is an oral tradition inherent in the culture of the people and handed down from one generation to the other. This is why it is not easy to date back its origin. A child born into a house where Ogun is worshipped is not necessarily formally taught the norms of the cult. Rather, he picks it up gradually from those around him. This is because Ogun plays a very prominent role in the daily affairs of the life of the people. Ogun affects the basic societal institutions like naming ceremonies, marriages, burials and initiations, to mention but a few. This will also be discussed later.

The historical settlement of Ogun in Ondo has highly influenced distribution of worshippers around the town. For instance, today, the base of Ogun worshippers is Ogbomkwo area which is mostly inhabited by the majority of the blacksmiths in town. This can be explained by the fact that this was the area where Ogun was said to have first settled on arrival at Ondo. So Ogun's impact was felt directly here. On the morning of the festival, you would see the excitement on the face of everybody. The people would be happy. From early in the morning, you would be hearing the heavy sound of pestles in the mortals as each household prepared pounded yam, known as iyan - Ogun. During the festival proper, there would be so many spectacular acrobatic displays and lot of choreographed dances by the celebrators.

By virtue of the fact that steel or iron is the basis of their occupation, the blacksmiths see themselves as serving Ogun directly. In other words, they esteem their work in a spiritual manner, because relative to all other worshippers (as shall be seen later), they have the greatest contact with iron (the basis of Ogun's power). This is also the reason why the blacksmiths form the bulk of the worshippers.

It is therefore not surprising that the growth of Ogun worship started from this area. With time, other places like Ododibo, Odojomu, Yaba and Okelisa sprang up as centers of worship. The factor binding all the worshippers in these areas is the predominance of iron in their occupations. Invariably this predominance of iron manifests power and greatness in their life.

\section{ROLE OF WORSHIPPERS IN OGUN FESTIVAL}

Ogun is one of the festivals in Ondo that attract people from far and near. Others are Odun Oba, Oramfe, Ekimogun day celebration etc. However, it will be worthwhile to discuss the role of the various groups of worshippers in relation to Ogun festival. Ondo people have a great respect for the office of the Osamawe, the paramount ruler of Ondo Kingdom. Like the other Obas in other Yoruba Kingdoms, the Osamawe of Ondo is hailed as Kabiyesi, Alase, Ekeji Orisa, the commander who cannot be questioned, second only to the gods. Western civilization has no doubt eroded into the stature of the Oba in the modern set up. Yet, the king remains very powerful personally within and outside his domain. 
The Osemawe of Ondo with other members of the royal family constitutes the head of all the worshippers. This is of great cultural and traditional significance because it is a pre - requisite for any heir to the kingship to be a staunch believer and worshipper of Ogun. It is commonly believed that the reign of an Oba who worships Ogun is likely to be more successful than that of an Oba who does not. This means that Ogun enhances the popularity of the reign of the Oba, and it also enables the whole community to be bound together under a "representative" of Ogun. This is advantageous to the Oba; he stands to gain the confidence of his subjects. The present king is, however, bringing some colour back to the carnival. He is said to be attracting some patronage to the Ogun festival, especially from corporate organizations.

\section{The Appreciation of Ogun in Ondo-Poetic Context}

An abundance of oral literature in Africa is fully preserved in poetic forms many of which are more developed in some countries than the other. There are various forms of Yoruba Oral poetry among which ofo 'incantation' is numbered. Ofo is an incantatory poetry compared more or less with the praise epithet on gods, personages, plants, animals, and the like. Ofo in actual fact, according to Olatunji (1984) in his article "Symbolisms in Yoruba Traditional Incantatory Poetry Vol. IV", is one of the Yoruba poetic forms recognised by their characteristic internal structure. It is a verbal externalization of the enchanter's feelings carefully coined to instill fear on, or bring a sort of psychological imbalance to the hearers. This imbalance is generated by a general belief among the Yorubas that there is always an existence or the presence of a dynamic vital force reminiscent or inherent in nearly all objects - animate or inanimate, human or superhuman objects and things.

This force, as the belief holds, could be conjured to help or aid any person in trouble, or condemned in all its entirely. This means then that incantations could be used both as a means of protection against any attack, or used as an evil end with which a total annihilation of an enemy and his evil machination could be achieved.

Incantatory poems in Yorubaland are of various kinds ranging from those that demand immediate result to those ones meant for certain occasions or seasons - but the one in question is for Ogun deity during the occasion of Ogun festival in Ondo. With this general background, on Yoruba traditional oral poetry, therefore, let us consider the poetic aspect of Ogun deity during Ogun festival in Ondo in their various styles, forms and categories.

As the head of all worshippers therefore, it is the duty of the Oba to declare Ogun festival officially open. This is usually done a day before the general ceremony. It is marked by several rituals which he has to perform at his palace on behalf of his people. These rituals are performed to propitiate Ogun and ask for a life more abundant for the future. These rituals are accompanied by incantations and chants in praise of Ogun's past achievements. On the following day, which is the day when the real festival actually takes place, other members of the royal family join the worshippers in the day's festivities. The Oba intones this incantation as he makes the sacrifices:

Incantation

1.Ogun Lakaiye

Ogun Onire Osinmole

Olomi nile fejewe

Olaso nile fimo kimo bora

5. Ogun

Meje l'ogun

Meje nire

Ogun tode ni jaja

Ogun toloda ni meje eniyan

10. Ogun molamola ni jekuru funfun

Ogun onipanjama onje igi lo nmu

Oto ni ti olode pakute

To baji papa ode ni itoro

Aso ina ni aso egungun

15.Aso mariwo ni aso osanyin

Ni ojo ti Ogun nti ori oke bo

Aso ina lo mu bora
1.Ogun

Translation

Ogun of Ire, the most important of the gods

Ogun that has water at home but bathes with blood

Ogun that has cloth at home but wears palm frond

5.There are seven types of Ogun

Like there are seven types of Ire

Ogun worshipped outside is worshipped with dog

The Ogun of hunter's drinks human blood

Ogun that foretells the future eats white ekuru

10.Ogun

Another Ogun is that of rabbit hunters

which takes care of the hunters wishes

The masquerades cloth is made of fire and blood

Osanyin cloth is made of palm frond

15. When Ogun was descending from the hill

He was covered with a garment of fire and blood 
Ewu eje lowo so run

Oya kin won lagbede

20. O wa тети

Ni ojo na ni Ogun kan ko ile aro

Ni okan ko ko ile aro

Ni ojo no ni Ogun kan yan odede imo

Ni okan oyan odede imo

25. Ni agbara wa fi ile okan sode

Oro Ogun ni oro ewo

Oro Ogun soro

\author{
He paid a visit at the goldsmiths' \\ He was offered palm wine \\ coincidentally that day one Ogun was building a fortress \\ While another Ogun did not build a fortress \\ One built a verandah covered with palm frond \\ 20.While another did not build a verandah covered with \\ palm frond \\ Torrents of rain then came and swept off weaker fortress \\ 25.Ogun's matter is treated with secrecy \\ Ogun's matter is treated with respect
}

\section{Comments AND Analysis}

This incantation is usually recited like a poem, indeed, in the context in which it is used, it is a poem chanted to the praise and glory of Ogun. The subject of the poem is Ogun. This poem can be regarded as an "epic" in the sense that it celebrates the prowess and valour of Ogun. This is aptly achieved through the use of several images. These images are applied to describe Ogun's qualities.

The poem starts with an invocation of Ogun in the first line. The word "Lakaiye" does not mean anything in particular because it is one of Ogun's appelation. This invocation is continued with a praise of the strength, fame and glory of Ogun. He is called the most important of gods. To substantiate with evidence why he is so - called, we have the metaphorical phrases in lines and 3 and 4. The fact that Ogun prefers to "bath in human blood" is an effective way of describing his thirst for blood at war and thus his military prowess.

Palm frond is regarded as Ogun's traditional "cloth". This distinguishes him from every other person and this is why Ogun worshippers tie palm frond round their waist while serving Ogun. It is a symbol of Ogun. We notice that in the first four lines of the poem, Ogun is persistently mentioned. This is to heighten the feeling of sacredness that the invocation of Ogun provides.

The analysis of the several types of Ogun that exist shows the various ways Ogun can be worshipped in other words, Ogun takes dogs, human blood, ekuru, etc. the fact that there are several types of Ogun shows the diversity of Ogun powers and the fact that each Ogun has specific function which it performs and as such should be worshipped accordingly. The phrase "Aso ina ni aso egungun" is a very metaphorical one which means literally that the apparel or garment of the masquerade is charged with fire, in other words the masquerade itself is fierce and induces great fear into people. In line 15, another allusion is made to palm frond - "mariwo", as Osanyin's (Ogun) garment i.e. the symbol of his power. The analogy being built up is developed in line 17 and 18:

\section{Aso ina lo mu bora}

Ewu eje lowo so run

In other words, when Ogun appeared from the hill - top, he was covered in a garment of fire and a blood - stained cloth. This is a metaphorical statement because its underlying meaning is that his cloth was blooded - stained further affirms his valour at war, it symbolizes his prowess at overcoming his enemies because it was not his blood but theirs. All these complex imageries are introduced wittingly to create a picture of awe around Ogun.

The significance of calling at the blacksmith's and talking palm wine affirms the sacredness of blacksmithing because it involves solely the use of iron implements. It is an occupation dedicated to the worship of Ogun as far as the blacksmiths are concerned.

Lines 21 to 25 can be likened to the Biblical parable of the man whose house built on a rock sustained the floods, unlike his counterpart's which was built on sand and as a result, washed away. The fortress and palm frond here symbolize Ogun's powers. So, anyone that has the faith in these powers will always be delivered. Thus, this simple argument is establishing and confirming the reliability of Ogun's power. It is a very effective argument because it is developed logically. The repetition of the word "Ni" in lines 21 to 25 is introduced to maintain the train of thoughts as the argument is developed. It is also for emphasis. 
The poem is rounded off with an assertion of the idea that Ogun's matters are to be treated with care and respect which heightens the sacredness which the whole poem commands.

Next in status to the Oba are his warrior chiefs, who, for defence purposes, are required to live in strategic parts of the town. Like the Oba, they are obliged to pay allegiance to Ogun by virtue of the fact that as warriors, they rely greatly on Ogun's power and assistance at war. Their war implements are made of iron so here too, they cannot dissociate Ogun from their lives. Thus, from the examples of the Oba and his warrior chiefs, we can see Ogun influencing the traditional dynastic requirements of the society because they all worship Ogun. Also, we can easily deduce that members of the ruling class are bound together by common unique factor - Ogun worship.

The head of the warrior chiefs is called the Ojomu of Odojumu. Four other areas of the town where the other warrior chiefs occupy are Okelisa, Onakere, Odosida, and Ododibo. During the Ogun festival, these areas are the five most important centers of congregation for worship. Major rituals and ceremonies are performed in groups in each of these areas by the respective warrior chiefs. The ceremony at Odojumu is the most remarkable because the Ojomu lives here and there is a myth surrounding his power. Long ago, "Ojomu nla" a very renowned warrior, as the little suggests sought Ogun's spiritual assistance at war. He received a special matchet from Ogun with which he fought and won his battles. From that time, this matchet has remained in a shrine outside the Ojomu's house. The matchet stands as a symbol of Ogun's spiritual presence with the Ojomu. As such, every year during Ogun festival, the Ojomu performs certain rites at this shrine, in the particular place where the matchet is kept. This is regarded as a pro - pritiatory rite to Ogun, the source of his power. While performing the ceremony, he praises Ogun's prowess at war, acknowledges his supremacy over all that is made of iron and asks for power with which to protect his town at war. Usually, he intones this incantation:

\section{Incantation}

Ogun alade nla

Ogun onire osinmole

Opon mi sile feje we

Alagbada ina

Eimi no ho

$\mathrm{O}$ fen jo ju juoriho

Aguntan to pon bose tere tere

Aguntan merin ese mejo

Agbado gbogbogbo jina negbe meji

Taka taka kala leisaje

O nlo ni gbo

Ariwo gbo gbo

Ogun nlo lodan okiki gb'odan echoed with loud reports of him

Ade lori olu

Onlo ni gboro iboosi gb'ode kankankan people gave him a tumultuous applause

Okurin gbongbon gidi

Okunrin gbongbon gidi

Okunrin wa okunrin wo

Okunrin wawa wowo

Okunrin gboin gboin gboin
Translation

Ogun who wears a large crown

Ogun of Ire the most important of the gods

Has water at home but prefers to bath with blood

Dress in garment of fire

killer in Owo

More fashionable than eyes or head

Red sheep with long elegant legs

Four sheep with eight legs

Longish maize roasted in the middle

taka taka kala leisaje

When he was passing through $a$ in the middle

The forest resounded with a might noise

When was passing through the savannah the savannah

Ogun wearer of a crown that is nonpareil

When he was passing through a town a huge throng of Man of timber

Man of calibre

Man of fame

Man of everything 


\section{COMMENTS AND ANALYSIS}

This incantation is directed towards its subject Ogun, it signs the praise of his fame, glory, physical appearance, and prowess. Several imageries are used in describing these. The first five lines lay much emphasis on his greatness and fame. The first line is metaphorical because it implies that Ogun is the greatest of the kings. So "large crown" here is symbolic. The same thing applies to the phrase: "Alagbada ina" which represents the fierce look and appearance Ogun "wears" around. In ondo dialect "Eimi" is another word for murderer or killer, this aptly describes Ogun's ruthless and merciless way of destroying.

Line 6 is very figurative but effective too. It is believed that one starts beautifying their face by making up the eyes and dressing the hair, in other words particular attention is paid to these two essential parts of the face. Ogun is compared to these two features and is said to be more "fashionable" in physical appearance than them. This is extended simile. Still in continuation of the praise of his physical appearance, a subtle comparison is drawn between Ogun and a "tall elegant sheep". Part of the mystery surrounding Ogun is emphasized by the fact that he is called "four sheep with only eight legs", further he is likened to a longish maize roasted in the middle. These are all metaphorical concepts ascribed to Ogun's elegant physical appearance.

Line ten is a sort of "Cliché" which is usually introduced into incantations on Ogun for its sound effects. Line 12 is onomatopoeia because of the phrase "gbo gbo" which sounds like an echo one will actually expects from the forest. This line makes one imagine the loud foot steps of Ogun as he passes through the forest, so it is an effective poetic device. Line 11 to 15 describe the "thunderous" effect Ogun has on his surrounding and people, which makes one imagine his physical strength and frame. This idea is continued from lines 16 to 20 , the language of the phrases does not mean anything in particular, it only involves the use of onomatopoeia to create a meaning and feeling. For instance, repetition of "gbongbo gidi" in lines 17 and 18 gives one the impression of a sound device used to express great strength and power. This is also applicable to the last line. It should also be noticed that a falling iron rod will produce a similar sound if it touches the ground. So, this sound device is an effective one, because it is expressing the power and strength of Ogun.

The whole incantation is "epical" because it celebrate the glory and prowess of Ogun. However, it is a rather hyperbolical too especially in the description of Ogun's physical appearance and the glory it commands. Apart from this, it is effective in the sense that it conveys the intended feeling of awe in a person. As soon as this ceremony has been performed, the Ojomu then runs round the town, chanting these incantations as he goes along. He later joins the procession of other worshippers in the day's festivities.

Ogun is also worshipped mainly by all users of iron implements. Therefore, he is the patron of hunters, blacksmiths, carpenters, soldiers and other artisans. On Ogun festival, they all come out to celebrate. Usually, they are grouped according to their professions. Thus we can see that people of different professions and occupations are brought together during the festival to pay allegiance to one god, being that they are all users of iron implements. From this, we will see that it is a festival which involves majority of the members of the society because iron is a very predominant metal in most articles of day to day life.

It is also essential to mention that Ogun worship in Ondo involves men, women, adults, and children alike. This they attribute to the fact that when Ogun left Ile - Ife for Ondo, he came along with all the members of his family including his sisters -in -laws, which shows his high sense of a feeling of unity amongst people. In other words, the people believe it is necessary to allow everyone to participate because it will strengthen the bond of togetherness within the families and the society at large.

\section{MODE OF WORSHIP AND ITS IMPORTANCE}

Ogun worship all over Ondo involves basically the same procedure with very little variations. This is why it can take place anywhere and can be performed by any individual. However, before a person is qualified to participate in the worship, he has to undergo certain rituals performed by some elders and Chief Priests. Also, he must be prepared to abide by the norms of the cult. The basis of the whole initiation ceremony as it is called is the acknowledgement of the supremacy of Ogun's powers over one's life. 
The worship is very ceremonious and it takes place in all homes where Ogun is recognized. These are the requirement for worship:

Any form of Iron (or stone in certain cases)

e.g - Cutlasses

- Iron Rods

- Matchets

- Axes

- Hoes

- Guns

All these symbols of Ogun, represent his spiritual power, so the atmosphere becomes a sacred one.

Other articles are:

- Cold water

- Palm Wine

- Palm Oil

These are regarded as Ogun's favorite drinks, to quench his thirst.

The third category consists of Ogun's food, namely:

- Dog

- Kola

- Fish

- Tortoise

- Rat

- Snail

Palm frond represents Ogun's cloth and this is why when an individual is worshipping the deity, he must not wear any form of material cloth but will only have palm frond tied round his waists. The dog is a sacred animal to Ogun, this is why it is used for the ceremony.

To begin the ritual, the worshippers first invoke the presence of God Almighty. This is done in recognition of the fact that Ogun derives his power directly from God. Then, someone draws back the hind - legs of the dog tautly, the same applies to its fore - legs, then another person cuts its neck with just one stroke of the sword. Immediately, the crowd raises a tumultuous shout. If the head is able to fall off with just one stroke from the sword, it means the sacrifice is acceptable to Ogun. The blood of the animal is then spilt over the remaining articles, as the worshipper chants songs, incantations and prayers to Ogun. These are the same as the ones used for Ogun festival, since the songs and incantation are used by the different professional groups, they are coined to suit each group. Another point to note is that these songs are not formally taught or written out. Because they have been imbibed in the oral tradition of the people, a new convert only picks them up through subsequent interactions with other worshippers. These songs serve inspirational functions too. Every farmer, hunter, or blacksmith to mention but a few, has various songs which they sing at work. Some of them are even sung together with folktales, while others are used for important occasions - burials, naming ceremonies, etc. Here are a few examples of these songs which are in honor of Ogun:

\section{SONGS}

1. Ogun la loja Ejigbo

\section{Chorus}

Ogun la o

Loja Ejigbo

This is a song in praise of Ogun as the Oloja of Ejigbo which is a village a few kilometers away from the present day Ogbomoso. It is usually repeated over and over as the people dance along. It is not 


\section{Dr. Olu-Osayomi Olusegun}

peculiar to any group of people so everyone sings it. It can be interpreted as Great Ogun the Oloja of Ejigbo. This song is sometimes sang during folktales or myths on Ogun. It is also sang if Ogun is being worshipped. However, usually, it can serve all purposes.

\section{Ijaye posa o eeeh}

Ese se nibe o?

Awa o

The hunters and blacksmiths usually sing this song. It will lose its original meaning if a direct transition is attempted because it is a war cry. The second line is a question "who goes there? then the answer is given in the third line "we". This song, apart from the fact that it is sang during Ogun festival, it can also be sang when a corpse is being accompanied home from the farm. Hunters use it to create an effect of fear on any impending enemy. The soldiers also use it to instill fear into their enemies in the battle front. Above all, it enhances the spiritual impact of awe on the people's life.

\section{Ise Ogun o}

Ise Ogun o

Ise Ogun o aro agbede

This is a song of the blacksmiths, the message it conveys is that the work of Ogun or Ogun's occupation is the cult of blacksmiths. So, apart from the fact this song sings the praise of the occupation of blacksmiths, it also professes that it is a sacred occupation because it is the cult of Ogun.

\section{Eroo}

Ero o

Alagbede aroye

This is another song peculiar to the blacksmith, it can be described as a prayer urging the blacksmith to work conscientiously until he reaps the fruits of his labor, which is prosperity rather than death or loss.

These last two songs are sang by blacksmiths especially during work because they serve as a source of inspiration and devotion to duty.

These songs are usually short because since they are not formally written or taught, it will be easier for the individual to pick them up after interaction with other worshippers. So, they form a part of the oral tradition of the people. Those of them that are sang during folktales for example, increase the entertaining effect of the story. Some of them help to set the norms and values of the society.

\section{OGUN AND SOCIAL HARMONY IN ONDO}

So far, we have traced the origin of Ogun and the way it is worshipped. Also, we have seen the influence these have had on the culture of the people. As earlier mentioned, unity is a key point which Ogun cult has achieved. For instance, one finds that Ogun worship is so prominent in Ondo that transcends religious, social and political barriers. This unity is further enhanced by the annual Ogun festival. This festival can be described as a dramatic form of oral literary activity, organised to propitiate Ogun, cleanse the town and seek for blessings for the future. Above all, this festival has a very strong impact on the society. Apart from the fact that it is the most significant local festival among the Ondos, it also carries as much importance as any festival like Christmas. During the festival, Ogun is worshipped as a "national god". This festival can be used as a "yardstick" for determining the extent to which Ogun has influence the people, because it is on that day that one discover the percentage of the people in the society that are involved in Ogun worship.

Throngs of people steam out, gaily dressed, carrying or wearing various forms of iron implements. This signifies the spiritual presence of Ogun and their acceptance of his power. They all dance, sing, drum, and perform acrobatic feats. It is believed that as they do these, they are frenziedly carried into the spiritual world. To a great extent, this is true because many of them can be in this mood for a very long period without showing any sign of tiredness. As s result, their action is not only physical but spiritual as well. This spiritual mood is further heightened by the presence of masquerades which 
represent Ogun. These "supernatural actors" command a sacredness by their incantations and songs as they lead the procession. They also perform certain rituals by killing dogs and they dance around the town. Everything is geared towards the glory of Ogun's interest. Prayers are said for protection in form of incantations:

\section{Prayer}

1. Ogun Lakaiye ma jeki apade alusi

Ti won npe ni jamba

Ma jeki apade warum loju ode

Iba ni ti Ogun

5. Ayanran ti nwo fi nти oti

Ogun loni ile

logun loni oko

Bi e ba gun yan efi t'ogun sile

Bi e ba ro oka eya ra fi t'Ogun sile

10. Nitori Ogun lo roko

Ogun lo ko ebe to gbin isu

Ti o roko mo isu

Ti isu fi jina wan
Translation

Ogun do not let us meet with harm

Which is called accident

Let us not meet with small pox outside

Homage is to Ogun

The dryer of meat with which drinks are accompanied

Ogun owns the house

Ogun owns the farm

If you pound yam, keep some aside for Ogun

If you prepare yam - flour keep some aside for Ogun

Because Ogun tilled the field

Ogun made the ridges and planted the yam

Ogun tended the yam

Until the yam was cooked and pounded.

\section{Comments AND ANAlysis}

The first three lines are dedicated to Ogun to safe guard the people against impending dangers. From lines 5 to 13 , reasons are given why homage should be paid to Ogun. He is always involved in the accomplishment of all things. This is why Ogun is said to rule the house and farm. In other words, iron implements are very prominent around the house and they are also used for farming which is the source of food for survival. This is why people are obliged to "give" Ogun some of this food. In other words, they should invoke the spirit of Ogun into the presence of the meal. The subject matter of his incantation can be said to be acknowledgement of Ogun's supremacy and predominance over the life of the individual. This is why prayers are said to Ogun to guard and guide the town.

Also, it is only on this day of the festival that all the members of each professional group collectively make sacrifices to Ogun to seek for protection throughout the following year. For instance, the drivers all go off the roads on that day and come together to ask Ogun to purify and guard their paths from all evils and dangers. The same procedure is applicable to the hunters, blacksmiths, carpenters and soldiers to mention but a few. They all offer prayers together:

Awa o ni ri ija Ogun o

Omo wa ko ni ri ija Ogun o

Ogun a gbe ile ati ona wa
We will not see the wrath of Ogun

\section{Our children won't see the wrath of Ogun}

Ogun will guide and guard our lives

These are prayers which are said with the deepest sincerity imaginable because they are believed to cleanse the evils and dangers of the society and everyone who does not join in the prayers is said to run the risk of falling victim to impending dangers. This is a psychological feeling though.

\section{CONCLuSION}

From the above analysis, it is evident that Ogun deity plays a prominent role in the life of the Yoruba and their community. In fact, in Ondoland, Ogun cult is a way of thinking and behaving. It is therefore, a way of life. It has transcended traditional, christian and muslim beliefs. Since it is deeply rooted in the culture of the people, it is essential to preserve its indigenous nature. This is why Ogun festival should be celebrated annually in Ondo. It helps to re - enact the norms and values which constitute an important part of the culture. Moreover, the culture of a society is its source of uniqueness and self - realization. Obedience to injuctions of Ogun deity leads to prosperity and prosperity and peaceful co - existence, while disobedience brings doom. "This is a testimony to the major role that the transcendent, the mysterious and the metaphysical play and continue to play in the life of the people depite the presence of the trappings of modernization" (Faniran, 2010:497).

Importantly also, this paper has examine the complex and rich poetic aspect of Ogun deity in relation to Ogun festival in Ondo which is still very much in existence in today's literature. Also, Ogun 
festival with its rich literary features is not only a source of unity but also a form of dramatic expression of these literary qualities. The opinion of this paper is that its use should be encouraged and not condemned because it is a tradition that the Ondos has identify with. It is an index of the cultural experience of the Ondo, a symbol of their social and cultural identity. It is therefore hoped that its adherence will assist in resolving some of the socio - political difficulties of Nigeria in the drive towards engendering a collective form of human advancement.

\section{REFERENCES}

Adeboye, Tope (2010). “Great Cities”. In : Explore Newspaper. Lagos: Explore Newspapers Ltd. Awolalu, Omosade (1979) Yoruba Beliefs and Sacrificial Rites. Essex, UK: Longman Group Ltd.

Faniran, J.O (2010) "Yoruba Video Film and the Visual Rhetoric of Communalistic". In: Journal of Cultural Studies, Vol. 8. Udu Yakubu (ed.) Lagos: African Cultural Institute.

Farrow, S.S. (1962) Faith, Fancies and Fetish of Yoruba Paganism. London: Society for Promoting Christian Knowledge.

Idowu, Bolaji (1962) Olodumare God in Yoruba Belief. London: Longman.

Lucas, J. O (1948). The Religion of the Yoruba. Lagos: C.M.S Bookshop.

Maduakor, Obi (1991). Wole Soyinka: An Introduction to his Writing. Ibadan: Heinemann Educational Books Nigeria Plc.

Mbiti, J.S. (1969). African Religion and Philosophy. Ibadan: Heinemann.

Ogunba, Oyin (2005) "Soyinka as an Evangelist of Ogun "Gege: Ogun Studies in English. Vol 1.

Oladele, B.A (2003). "The Belief in God (Olodumare) and Divinities in Traditional Yoruba Thought: Some Lessons for the Democratization Process in Contemporary Africa. In: IBA: Essays on African Literature in Honor of Oyin Ogunga (eds.). Wole Ogundele, Gbemisola Adeoti. Ile - Ife: Obafemi Awolowo University Press Ltd.

Oladipo, O.T (1998). An African Concept of Reality: A Philosophical Analysis. (Ph.D Thesis, Department of Philosophy, Ibadan, University of Ibadan.

Olatunji, O. Olatunde (1984). Features of Yoruba Oral Poetry. Ibadan: University Press ltd.

Olu - Osayomi, Olusegun (2013). Yoruba Divinities in Selected Nigerian Plays: Unpublished. Ph.D Thesis, Babcock University, Ilishan - Remo.

Omolafe, John (1998). "The Significance of Cosmology Categories" The Journal of Religious Studies. Vol. xxxix, No. 1.

Peel, J.D.Y (1994). "Comparative Analysis of 'Ogun' in Pre - Colonial Yoruba". Seminar, Institute of African Studies. University of Ibadan.

Samuel, Johnson (1957). The History of the Yorubas, from the Earliest Times to the Beginning of the British Protectorate. Lagos: C.M.S. Bookshop.

Simpson, E. George (1980). Yoruba Religion \& Medicine in Ibadan. Ibadan University Press.

Sodipo, J.O (1973). "Notes on the Concepts of Cause and Chance in Yoruba Traditional Thought" Second Order. Vol. 11, No. 2.

Soyinka, Wole (1976)."The Fourth Stage “. In: Myth, Literature and the African World. London: Cambridge University Press.

Uda, Yakubu (ed.) (2010). Journal of Cultural Studies. Vol. 8, No.1, 2 \&3. Lagos: African Cultural Institute.

\section{AUTHOR's BIOGRAPHY}

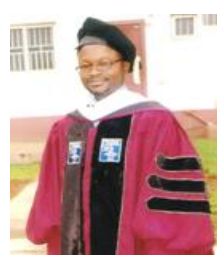

Dr. Olusegun Olu-Osayomi (FIPMD), born of Ekiti parents, is the author of many short stories, books ( one of which is The Secrets of Campus Cults), and biographies of the late Pa M.A. Ajasin, His Eminence S.C. Mbang, Rev.(Dr.) W.A. Badejo (unpublished), Sir (Dr.) E.J. Amana, Prof. P.B.Ikulayo, and Prof.G.B.Onolaja, among others. Dr. Olu-Osayomi, journalist, poet, biographer, literary theorist and critic, is a talented scholar and researcher. He obtained his $\mathrm{PhD}$ in English specializing in

Cultural Studies, and he teaches Drama, Poetry, the African Novel, Creative Writing, and (Auto) biographical Studies at the Department of Languages and Literary Studies, Babcock University, Ilisan-Remo, Ogun State, Nigeria. He was formerly the Head of the Department and has won many honours and awards. 